\title{
FEATURE Impact of levee breaches, flooding, and land scouring on soil productivity
}

\author{
Kenneth Olson, Jeffrey Matthews, Lois Wright Morton, and John Sloan
}

$\mathrm{F}$ looding of agricultural lands after a natural or human-induced levee breach can have large and persistent effects on soils, crop productivity, and water quality, with negative economic, social, and ecological consequences. Many US water management strategies associated with levee-protected agricultural systems are dominated by policies that focus on engineered solutions designed to minimize short-term risk of flooding and breaching while overlooking resilience of the agroecosystem as a whole (Morton and Olson 2014; Park et al. 2013). A federal damage assessment of the effects of levee breaches and flooding on public and agricultural lands is needed each time a levee fails. Most federal damage assessments only include the levee itself and the adjacent crater lakes, gullies, and sand deltaic deposits but not the remaining flooded areas. Land scouring, sediment deposition in drainage and road ditches, and soil productivity loss are the most severe damages to soils on agricultural lands.

Levee breaches on the Mississippi River in the US interior have occurred since the Great Flood of 1927 (Barry 1997). The Flood of 2011 (Camillo 2012) on the Mississippi River well illustrates the impacts of flooding and levee breaching on agricultural soil conditions and productivity. The area of study for this paper is a $78 \mathrm{ha}(195 \mathrm{ac})$ field on O'Bryan Ridge (3551'09” N, 89¹1'03” W) owned by Levee District Number 3 that

Kenneth Olson is a professor of soil science in the Department of Natural Resources and Environmental Sciences, College of Agricultural, Consumer, and Environmental Sciences, University of Illinois, Urbana, Illinois. Jeffrey Matthews is an assistant professor of restoration ecology in Department of Natural Resources and Environmental Sciences, College of Agricultural, Consumer, and Environmental Sciences, Urbana, Illinois. Lois Wright Morton is a professor of sociology in the Department of Sociology, College of Agriculture and Life Sciences, lowa State University, Ames, lowa. John Sloan is a watershed scientist, National Great Rivers Research and Education Center, Lewis and Clark Community College, Alton, Illinois. was impacted when the US Army Corps of Engineers (USACE) opened the New Madrid Floodway in Missouri by inducing a breach in the Birds Point fuse plug levee on May 2, 2011 (figure 1). An unintended conversion of agricultural land to wetlands and ponds occurred within the land scoured bottomlands (figures 2 and 3 ) in the O'Bryan Ridge field. These gully lands have since been partially regraded and reshaped in an effort to return the agricultural land to production.

The dramatic changes in land use from levee breaching demonstrate the need for a land scouring and deposition survey, an updated soil survey, and a soil and water conservation plan to reduce further soil loss and gully formation on reclaimed lands. An updated soil survey map with eroded and deposition phases of previously existing soils and new soil series can be used to estimate and compare the crop yields and production levels before levee breaching and after gully field creation and to guide the periodic reshaping and restoration of the gully fields. Further, gully fields within the New Madrid Floodway are likely to remain vulnerable to the next induced levee breach and subsequent flooding if a revised plan to protect the area is not developed.

\section{GULLY FIELDS ON O'BRYAN RIDGE IN NEW MADRID FLOODWAY}

On May 2, 2011, the Cairo flood gage reached a record $18.7 \mathrm{~m}(61.7 \mathrm{ft})$, and for the first time in 74 years, at 10:00 p.m. the USACE opened the New Madrid Floodway (figure 1) using $240 \mathrm{t}$ (265 tn) of trinitrotoluene (TNT). Approximately, $2 \mathrm{~km}(1.2 \mathrm{mi})$ of the fuse plug was blown up simultaneously in six places in the front line levee with one-fourth of the Mississippi River entering the $56 \mathrm{~km}$ (35 mi) long and 6.4 to $16 \mathrm{~km}$ (4 to 10 mi) wide New Madrid Floodway. The Mississippi River floodwaters were 4 $\mathrm{m}(13.2 \mathrm{ft})$ above the base of the Birds Point fuse plug levee and adjacent bottomlands when the human-induced breach occurred. After the Floodway was opened, the floodwaters poured through

\section{Figure 1}

Location of O'Bryan Ridge gully fields in New Madrid Floodway. Map created by Mic Greenberg.

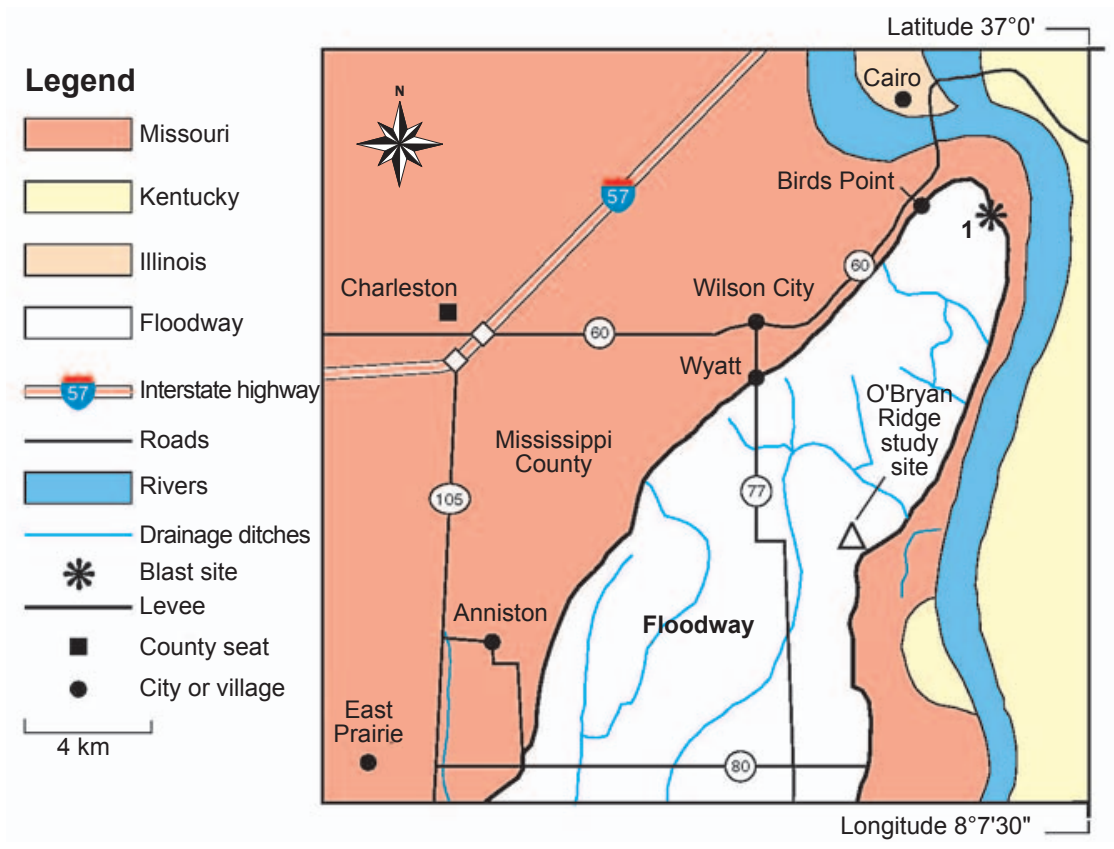




\section{Figure 2}

June 15,2011 , land scouring of the bottomland located below the gully fields.

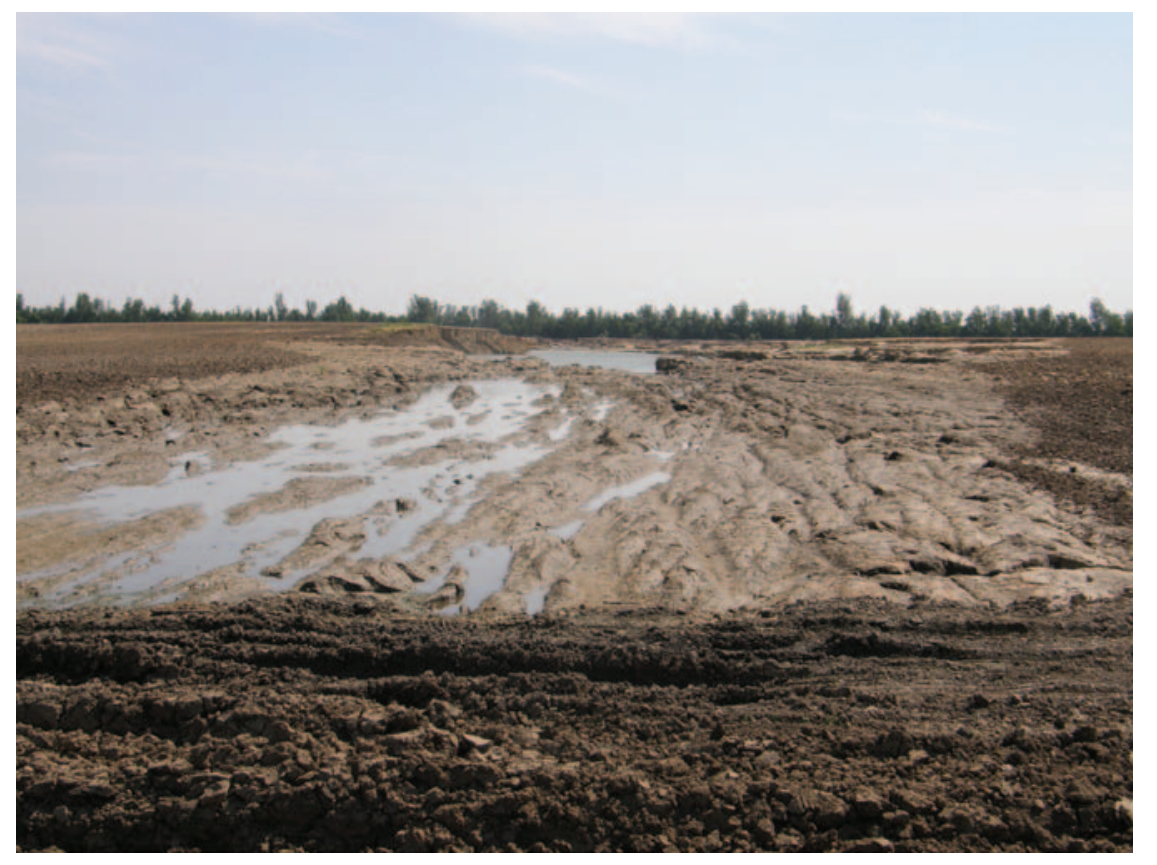

\section{Figure 3}

May of 2011 aerial view of O’Bryan Ridge gully fields.

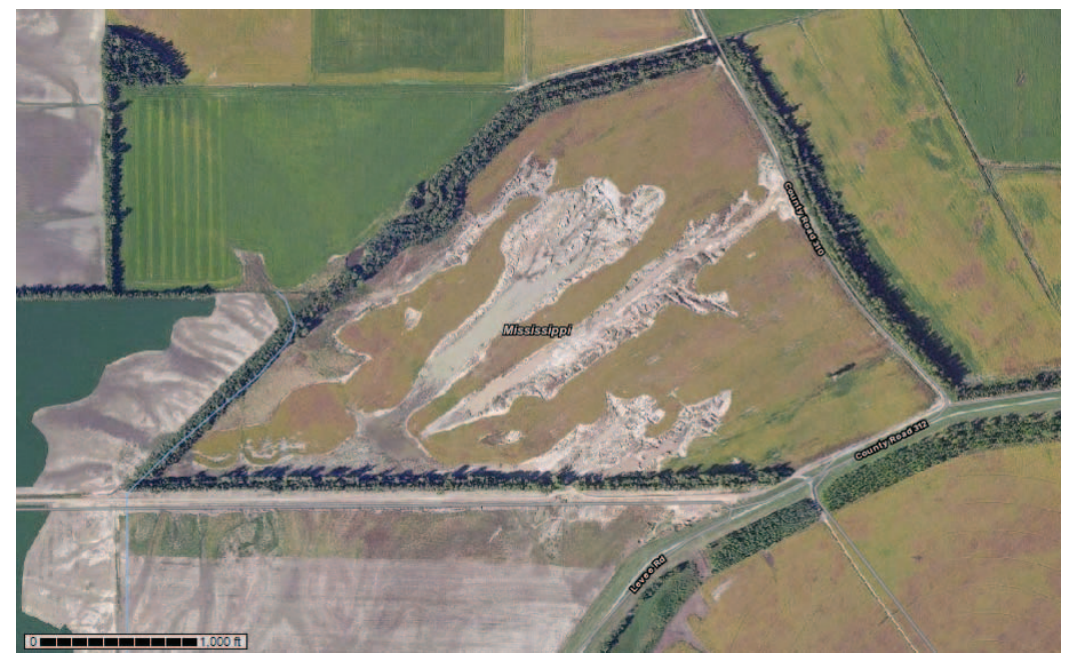

the levee breach and dropped onto the protected bottomlands creating a crater and then spread out into the $8 \mathrm{~km}(5 \mathrm{mi})$ wide Floodway. Since the Floodway was four times wider than the induced levee breach, the water level quickly dropped by a factor of four to an approximate average 1 to $2 \mathrm{~m}$ (3.3 to $6.6 \mathrm{ft}$ ) depth, depending on the elevation of the bottomland surface. The drainage ditches and road ditches had a greater depth of water (Olson and Morton 2012a).

By the time the leading edge of the floodwater reached the widest part of the Floodway, the water had traveled approximately $16 \mathrm{~km}$ (10 mi), and the average depth was further reduced by a factor of two to approximately 0.5 to $1 \mathrm{~m}$ (1.7 to $3.3 \mathrm{ft}$ ). As the water from the induced breach flowed south $32 \mathrm{~km}$ (20 mi), it merged with Mississippi River flood- water that had backed up into the lower third of the Floodway through the open gap between the frontline and set back levee at New Madrid. As a result, there was little land scouring in the southern part of the Floodway.

The floodwater eventually covered 53,200 ha $(133,000 \mathrm{ac})$. Along the way, 80 farmsteads and homes were inundated by $1 \mathrm{~m}(3.3 \mathrm{ft})$ of floodwater and severely damaged. The floodwaters ponded in front of O'Bryan Ridge, an old Mississippi River meander bank or natural levee, which was about 2 to $2.5 \mathrm{~m}$ (6.6 to $8.3 \mathrm{ft}$ ) higher than the alluvial bottomlands and approximately $10 \mathrm{~km}$ (6 mi) long and 1 $\mathrm{km}(0.6 \mathrm{~m})$ wide. Once the ponded floodwater reached 2 to $2.5 \mathrm{~m}$ (6.6 to $8.3 \mathrm{ft}$ ), the water began to flow rapidly over the soybean (Glycine max L.) field on O'Bryan Ridge. As the floodwater dropped off the ridge it concentrated in old drainage areas and waterways (figures 3 and 4), cut gullies into the alluvial bottomland (Sharkey soils) on the west side of O'Bryan Ridge due to hydraulic jumping, and created canyonsized gullies (figure 3 ) up to $1 \mathrm{~km}$ (0.6 mi) in length through the entire width of the ridge (Olson and Morton 2012a).

Three major gully fields were created on O'Bryan Ridge as a result of the induced breach (Londono and Hart 2013; Goodwell et al. 2014). Two of the gully fields were reclaimed in 2011 and 2012 by the land owners. In this paper we focus on the third major gully field (figures 2, 3 , and 4) to assess the effects of gullies on soil properties, soils, soil productivity, land use change, and agricultural production. This gully field was located $8 \mathrm{~km}$ (5 mi) away from the Birds Point levee breach and apparently did not qualify as a priority area identified by USACE as needing immediate restoration and repairs. All the priority areas including levee, crater lakes, and roads were restored by the fall of 2012 .

The disastrous consequences of severe erosion from the induced breach were probably not anticipated by landowners since the Floodway had not been used since 1937 (or in most landowners' lifetimes). The bottom of the trenches eroded more than $1 \mathrm{~m}(3.3 \mathrm{ft})$ below the bottom-

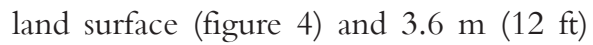
below the surface of the O'Bryan Ridge 


\section{Figure 4}

May of 2011 trees falling into channel and undercutting County Road 310.

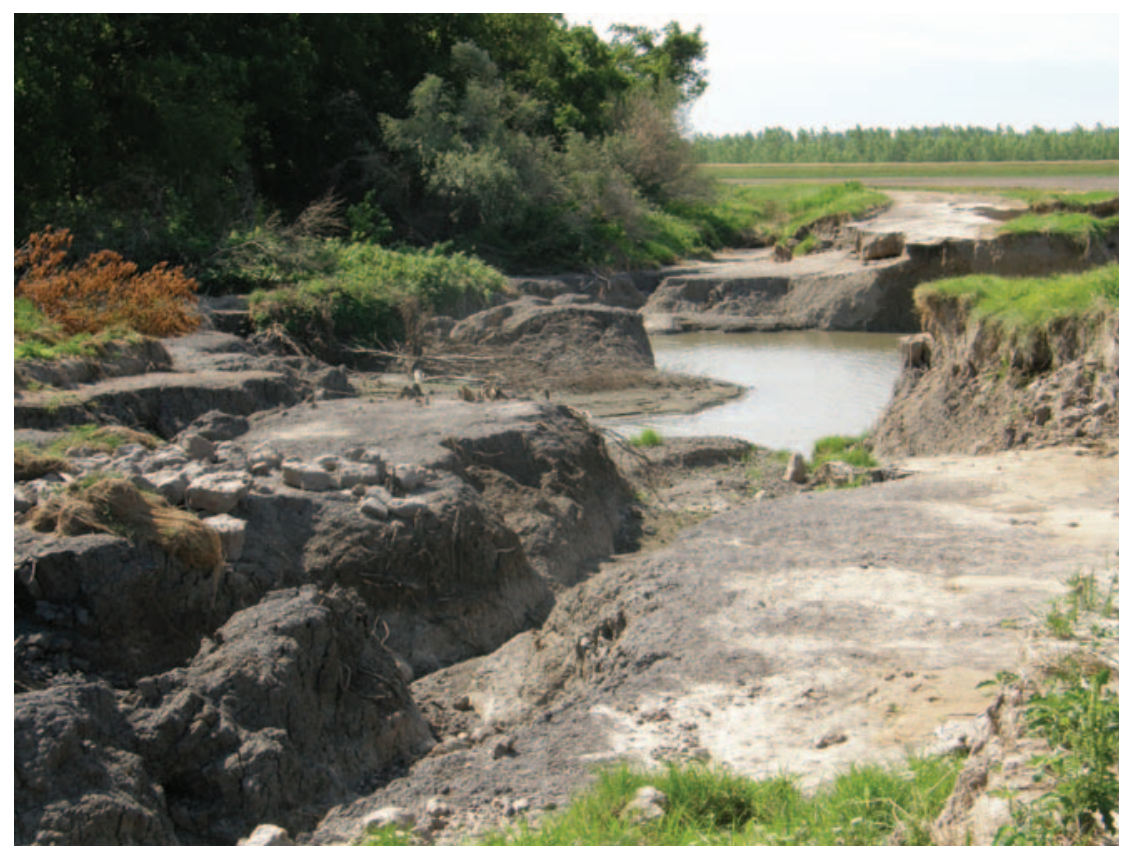

(Londono and Hart 2013; Goodwell et al. 2014). A channel was created $1 \mathrm{~km}(0.6$ mi) from west to east (figure 3), which undercut the gravel road (County Road [CR] 310) and extended into the wooded bottomland border area. A series of canyon-sized gullies cut into the O'Bryan Ridge in a dendritic pattern (figure 3 ). Some did not cross the entire $1 \mathrm{~km}(0.6$ mi) ridge. Other gullies cut through the tree line on the south side of the gully field, dissected CR 312 on the south of O'Bryan Ridge, and nearly reached a section of the adjacent frontline levee. The gullies between CR 312 and frontline levee did qualify as a USACE priority area and were reclaimed in fall of 2011 and spring of 2012.

\section{CROPS AND VEGETATION ON O'BRYAN RIDGE AFTER FLOODING}

The O'Bryan Ridge field with slightly eroded soils (figure $5 \mathrm{a}$ ) had been planted to soybeans in 2010. It was returned to soybean production by July of 2011, but 24 ha $(60 \mathrm{ac})$ of the $78 \mathrm{ha}(195 \mathrm{ac})$ field could not be farmed as a result of the deep gullies (figures 3 and $5 b$ ). Farm equipment had to be kept back from the $3.6 \mathrm{~m}$ (12 ft) high vertical edges of the gullies, and the land between the gullies could not be culti- vated (Olson and Morton 2012a). In June of 2011, the farmers needed access to their fields and USACE had to get to their levees for maintenance, so CR 310, on the east side of the gully field, was reconstructed by partially filling in a $3.6 \mathrm{~m}$ (12 ft) deep and 33 to $55 \mathrm{~m}$ (100 to $160 \mathrm{ft}$ ) wide gully (figures 3 and 4). The field was again planted to soybeans in 2012, 2013, and 2014. No attempt was made to reclaim the gully fields until the spring of 2013, or two years after Floodway use by USACE.

Ponds and herbaceous wetlands spontaneously developed in the gullies by 2013. The ponds that formed in the gully bottoms were $1 \mathrm{~m}(3.3 \mathrm{ft})$ below the first bottomlands and $3.6 \mathrm{~m}(12 \mathrm{ft})$ below the ridgetops. These deep gullies trapped water as well as whatever nutrients, pollutants, and contaminants the waters carried. The ponds and wetlands were partially filled in 2013 when the gully edges were bulldozed into the gullies to reshape and regrade the sides of the gullies (figure 6a). Once a soybean crop was planted on the Udifluvents sloping soils (figure 6a), sheet, rill and gully erosion occurred, and the sediment was transported by runoff water into the ponds and surrounding wetlands. In 2014, the remaining wetlands were dominated by early successional, herba- ceous plant species. Species accounting for the greatest cover at the site included hog peanut (Amphicarpa bracteata), a leguminous vine; giant foxtail (Setaria faberi), an annual grass; tall boneset (Eupatorium serotinum); and beggar's ticks (Bidens frondosa). In addition to these early colonizing herbaceous species, several seedlings and saplings of early colonizing wetland trees and shrubs, particularly eastern cottonwood (Populus deltoides) and willows (Salix nigra and Salix interior), were noted. If left unchanged, the gully wetlands would likely become forested wetlands on the gully slopes, and the shallow bottoms become semipermanently inundated ponds in the deeper gullies.

\section{ASSESSMENT OF THE RESULTING AGRICULTURAL PRODUCTIVITY CHANGE} Prior to 2011 Floodway use, the entire 78 ha (195 ac) O'Bryan Ridge field owned by Levee District Number 3 was in soybean production with no wetlands or ponds. The soybean crop averaged approximately $3 \mathrm{t} \mathrm{ha}^{-1}\left(44 \mathrm{bu} \mathrm{ac}^{-1}\right)$ with a total average of approximately $233 \mathrm{t}(8,550 \mathrm{bu})$ of soybeans per year. After creation of the gully field and scouring of the bottomlands and ridge, 20 ha $(50 \mathrm{ac})$ of the field became gullies and could not be farmed, and approximately 12 ha $(30 \mathrm{ac})$ between or adjacent to the deep gullies was not able to be planted. The remaining 46 ha (115 ac) were land scoured including the bottomland west of the O'Bryan Ridge. Thus, after the gully fields were created, a total of $50 \mathrm{ha}(124 \mathrm{ac})$ were in agricultural production and 28.4 ha $(71 \mathrm{ac})$ were wetlands and ponds (figure 5b). In 2013, 24 ha (60 ac) of sloping madeland or Udifluvents, was returned to soybean production from regrading 12 ha $(30 \mathrm{ac})$ of nearly level ridge land and 12 ha $(30 \mathrm{ac})$ of the gully bottoms with ponds (figure 6a). In the gully bottoms, approximately 16 ha (40 ac) became wetlands and ponds. The 30 ha $(60 \mathrm{ac})$ of the Dubbs soil, 5.6 ha $(14$ ac) of Sharkey soils, and 24 ha $(60 \mathrm{ac})$ of Udifluvents remained in agriculture- a total of 54 ha $(134 \mathrm{ac})$. In sum, even after 2013 land regrading, approximately 24 ha (60 ac), or $31 \%$, of the land had been unintentionally converted from agricultural 


\section{Figure 5}

(a) March of 2011 soils prior to levee breaching in the Floodway on O'Bryan Ridge. Cultivated Dubbs and Dundee soils form a natural levee to the east of Sharkey bottomlands. (b) May of 2011 soil eroded phases of O'Bryan Ridge showing soil loss and degradation with the creation of gully fields during the Floodway use and flooding. Maps created by Mic Greenberg.

(a)

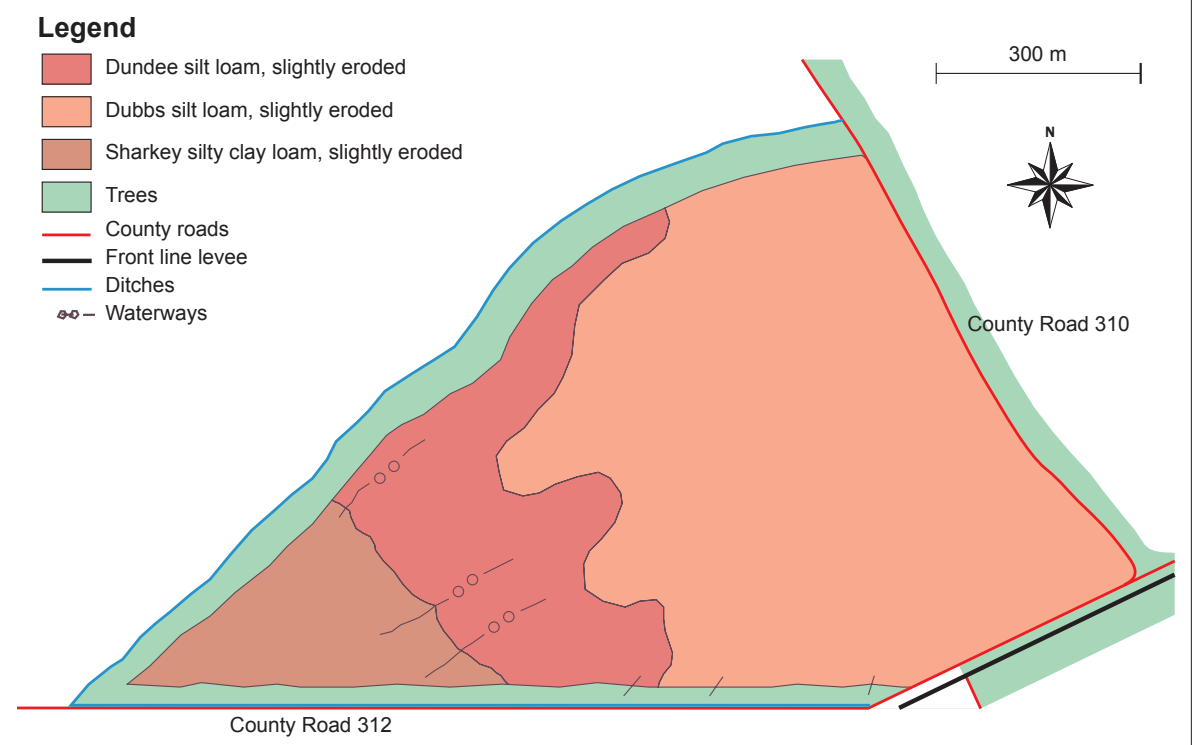

(b)

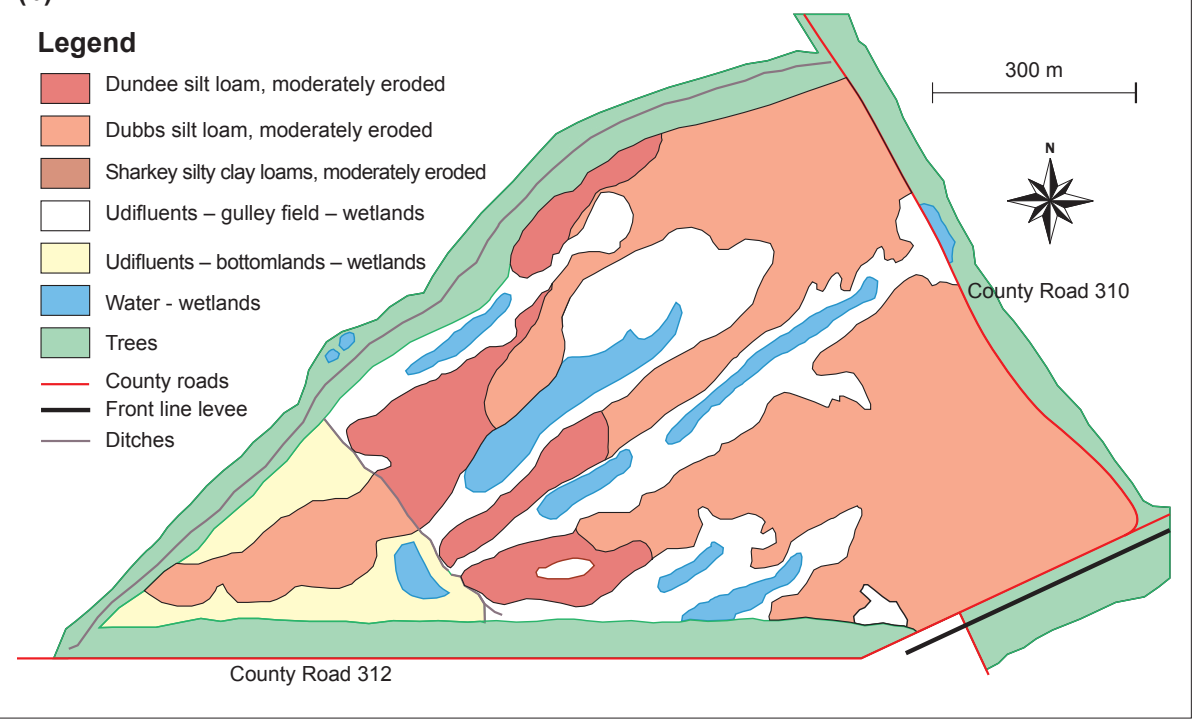

lands to wetlands and ponds as a result of Floodway use.

The productivity of all the eroded Dubbs, Dundee, and Sharkey soils was lowered. Soybean production was reduced from $3.1 \mathrm{t} \mathrm{ha}^{-1}\left(45 \mathrm{bu} \mathrm{ac}^{-1}\right)$ to $2.7 \mathrm{t} \mathrm{ha}^{-1}$ (40 bu $\mathrm{ac}^{-1}$ ) on the Dubbs and Dundee soils and from 2.7 to $1.9 \mathrm{t}$ (40 to $30 \mathrm{bu}$ ) on the Sharkey soils based on soil properties and erosion phase changes on the remaining 30 ha $(74 \mathrm{ac})$ of nearly level land either on ridge or bottomland scoured area (figure bulldozers pushed massive amounts of topsoil and subsoil from ridge tops into the gully bottoms, which eliminated most of the wetlands and ponds. This land redistribution continued until there was almost no topsoil and subsoil left on the ridgetops (figure 6b). This process of land reshaping reduced the slope from strongly sloping to gently sloping and reduced the erosion hazard. However, the filled in gullies are still lower than adjacent ridges and will remain vulnerable to the next use of the Floodway. This reclamation changed the land use again leaving only 10 ha (25 ac) remaining in wetlands and ponds and increased the agricultural land to 68 ha $(170 \mathrm{ac})$. The soil productive capacity of the O'Bryan gully field tract was raised to $163 \mathrm{t}(6,000 \mathrm{bu})$, reducing the permanent soil productive capacity loss to $30 \%$ from the $44 \%$ loss that occurred in 2011, the year the gully field was created.

Much of this loss of soil productivity and yield capacity on the land scoured, reshaped area, and the wetlands area was permanent. Even extensive reclamation efforts in the spring of 2014 (figure 6b) could only mitigate and restore part of the soil productivity and yield capacity loss. The land use change to wetlands appears to be temporary with the land being returned to agricultural use through grading and reshaping. The 78 ha (195 ac) Levee District field, which formerly produced an average of $233 \mathrm{t} \mathrm{y}^{-1}(8,550$ bu $\mathrm{yr}^{-1}$ ) of soybeans in 2010 , produced an average of $131 \mathrm{t}(4,820 \mathrm{bu})$ in 2011 and 2012 - a loss of $44 \%$ or 102 t $(3,730 \mathrm{bu})$ after gully field creation (figure $5 b$ ). After reclamation in spring 2013 and spring of 2014, the land produced $163 \mathrm{t}(6,000 \mathrm{bu})$, a loss of $30 \%$ or $70 \mathrm{t}(2,565 \mathrm{bu})$ of soybeans (figures 6a and 6b). In 2015, Levee District Number 3 plans additional earth moving in an attempt to further mitigate this permanent soil productivity and yield capacity loss. The source of the needed soil materials has not yet been identified, and there are only 15 ha $(37 \mathrm{ac})$ of topsoil and subsoil materials left on the tract (figure 6b).

\section{CONSERVATION RECOMMENDATIONS TO IMPROVE PRODUCTIVITY}

The attempt to reshape the gullies by regrading and filling with soil increased soybean production but had the unin- 
tended outcome of creating rills (figure 7). The negative impacts of the cutting and filling operations on soil productivity will need to be remediated by restoring natural ecological functions to the affected soils. Organic matter additions to the soil, such as biosolids and composts, decrease the bulk density of soils, increase infiltration rates and porosity, and contribute to better soil structure (Ruehlmann and Körschens 2009; Sloan and Cawthon 2003; White et al. 1997). The use of cover crops can also be an important management tool for protecting soils from erosion during dormant seasons and for reestablishing key soil quality indicators (Abdollahi and Munkholm 2014; Stavi et al. 2012).

The Udifluvents slope had little soil organic carbon (C) and aggregation in the surface layer. These madeland soils are now on $2 \%$ to $6 \%$ slope with an erosion rate above $66 \mathrm{t} \mathrm{ha}^{-1}\left(30 \mathrm{tn} \mathrm{ac}^{-1}\right)$. Many rills were created in 2013 as a result of soybean production on these sloping soils (figure 7). A conservation plan is needed for the entire 78 ha (195 ac) area but has not been created as of 2014. The new sloping land created in spring of 2013 (figure 6a) is too erosive and no longer suited to continuous soybean production without conservation practices. A terrace system and contour farming with grassed waterways will likely be needed to retain production under continuous soybean. No-till management does not provide a mechanical method to eliminate annual rills, which can quickly turn into new gullies. Alternatively, continuous soybean could be modified in favor of a rotation with corn (Zea mays L.), forages and wheat (Triticum aestivum $\mathrm{L}$.), which could make the soil less vulnerable to erosion. Had the 78 ha (195 ac) field had grassed waterways and been planted to winter wheat or had a cover crop and/or forages when the flooding occurred, the land scouring and gully formation would have been diminished. The middle and lowest parts of the gullies are no longer suitable for row crops and represent a significant land use change to wetlands and ponds.

\section{ROAD INFRASTRUCTURE}

The main $1 \mathrm{~km}$ (0.6 mi) gully remains partially open for future New Madrid Floodway use. However CR 310 was

\section{Figure 6}

(a) October of 2013 moderately eroded soils of O'Bryan Ridge after and shaping and grading of gully field to return more of the land to cultivation. (b) April of 2014 ponds drained and wetland areas partially filled with topsoil and subsoil from the Dubbs silty loam to create more cultivated land. Maps created by Mic Greenberg.

(a)

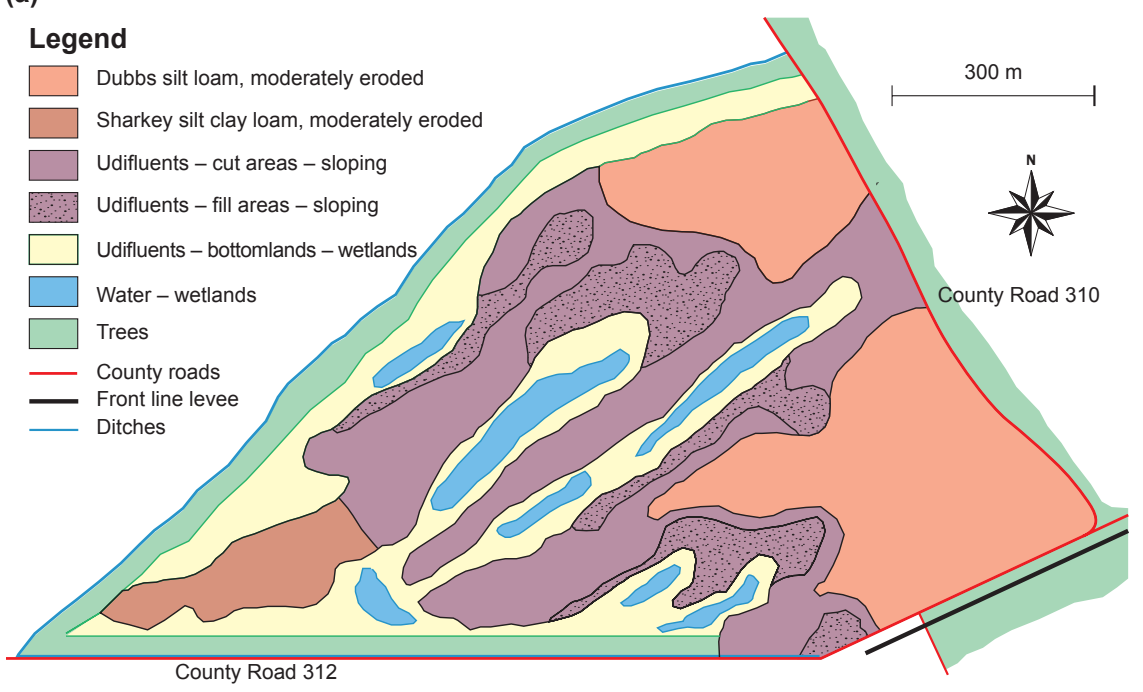

(b)

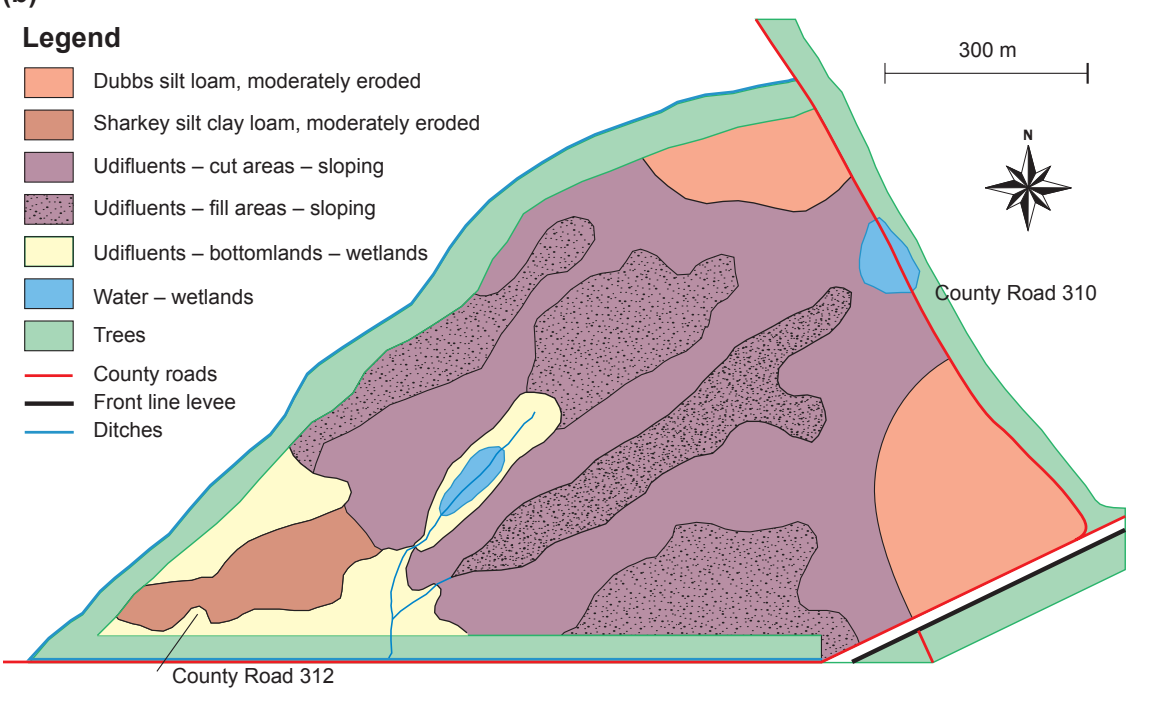

reconstructed across the largest gully without a culvert (figure 3). This road again will block future floodwaters until they flow over the road and with high probability convert the waterways into another gully field. This would dissect CR 310 in many more places. Future reclamation efforts would then be required and result in even more conversion of agricultural lands to wetlands and ponds. It is recommended that a set of large culverts be placed in the main channel to permit future floodwaters to flow through the partially filled in channel.

\section{DISCUSSION}

The USACE manages more than 22,000 $\mathrm{km}(14,000 \mathrm{mi})$ of levees protecting Mississippi River and tributary bottomlands in river plains, four floodways, and $19,000 \mathrm{~km}(12,000 \mathrm{mi})$ of river navigation channel and control structures (Morton and Olson 2014) with goals that include supporting flood risk management activities in communities and restoring aquatic ecosystems (NRC 2012). Many of these levees and floodways are financed, built, and maintained cooperatively at the watershed level by local farmers and 


\section{Figure 7}

Rill and gully erosion after soybeans planted in 2013 on regraded slopes and filled land.

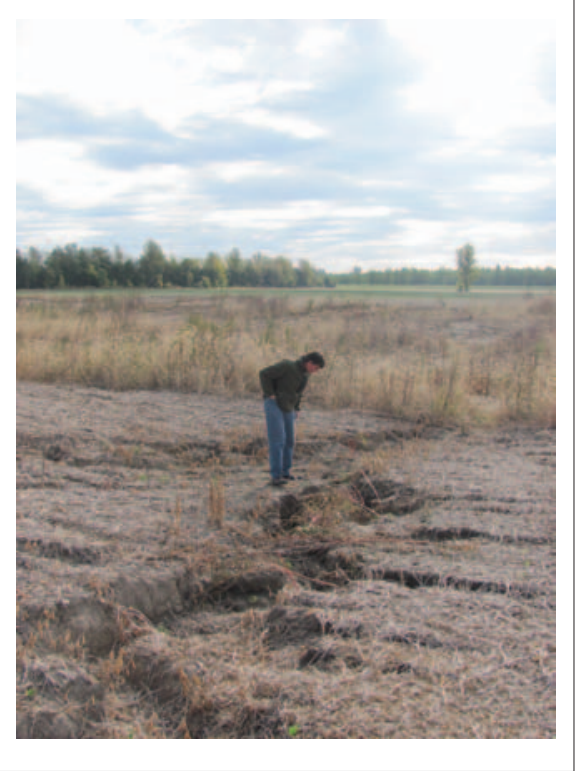

communities to protect their livelihoods and shared community infrastructures. Extreme flooding events, such as the 1927, 1937, 1993, 2002, 2008, and 2011 floods along the Mississippi River and its tributaries, illustrate the continuing challenges for river communities, industry, and agriculture. These complex issues are related to evolving natural disasters, downstream flooding, and increased water pressure on levee protected bottomlands (Lowery et al. 2009; Olson 2009; Olson and Morton 2012a, 2012b, 2013a, 2013b; Morton and Olson 2013, 2014; Londono and Hart 2013; Goodwell et al. 2014). Of particular concern are the vulnerability of low-lying environments that rely on levee protection and the direct impacts of levee breaching on hydrologic patterns, sediment transport and distribution, soil erosion, and land scouring, as well as the indirect impacts on socioeconomic activities, especially agriculture, of flooded areas.

Leveed river bottomlands are designed to protect human populations and various land uses including agriculture from flooding. When a levee fails, the damage caused by floodwaters and contamination of water and land is significant. Waterborne organo-clay sediments often cover plants and soils and fill in road ditches, drainage ditches, and waterways or re- enter water in rivers, streams, and lakes. Usually there are crater lakes created by floodwaters either topping or pouring through the levee breach and substantive gully development (Londono and Hart 2013; Goodwell et al. 2014). These gullies and land scour areas can extend into the floodplain such as the O'Bryan Ridge field site several kilometers (miles) beyond the breach into fields or along ridges (Olson and Morton 2012a).

The case of the O'Bryan Ridge site revealed that $31 \%$ of the land use was changed from agricultural use to wetlands and $44 \%$ of the agricultural productive capacity was lost as of 2013 due to erosion phase changes and reshaping of the gully sideslopes and soil reconstruction. Additional regrading efforts in 2014 affected the land use and restored some of the soil productivity and yield capacity of the tract to $70 \%$, but there was still a $30 \%$ permanent productivity loss. Further, little has been done to prepare the land for the next Floodway use.

The land scouring and erosional processes remove topsoil, create eroded phases and depositional phases on a soil and sometimes subsoil, and result in less productive soils even if land is reshaped and reclaimed (Olson and Lang 2000). The effects of sediment deposition and land scouring on soil profiles and productivity need to be determined so agency technical staff, local leadership, and farmers have information to guide decision making in order to effectively return lands to agricultural production and put in place strategies and infrastructure to address future flood events. Findings from the mapping of hydrogeologic patterns, characterization, and measurement of soils and water after being affected by erosion, transport, and sediment deposition as a result of flooding with or without natural and human-induced levee breaches can offer valuable guidance to the restoration of flooded areas and improve decision making, risk analysis, and remedial effectiveness as well as future planning.

The type of vegetation present in the floodplain can have a significant influence on the scouring, transport, and deposition of sediments during a flood event, especially when the floodwater carries a large amount of energy (Bruneta and Astin 2008). For example, during the 2011 flood and induced breach of the Birds Point fuse plug levee system, the field closest to the breach contained grassed waterways and a healthy stand of winter wheat, and the soil was mostly protected from scouring, whereas an adjacent recently tilled field further from the breach was severely impacted by scouring and loss of topsoil (Olson and Morton 2012a). The wheat residue fields also trapped more sediments than the soybean stubble fields. Feedbacks also exist between natural vegetation and hydrology in floodplains. Floods strongly influence the structure and composition of the vegetation, but vegetation contributes to hydraulic roughness and influences patterns of sediment deposition. As a consequence of these feedbacks, human-caused changes in river hydrology have complex effects on both natural and planted vegetation.

\section{CONCLUSIONS}

Levees protect public and private lands from the consequences of periodic flooding. However, when they fail naturally or as a result of human induced breaches the consequences are disastrous and can take different forms. The damages include crop loss; levee damage; crater lakes; gullies; thick sand deltaic deposits; land scouring; irrigation equipment destruction; soil and water degradation; building structure and farmstead damage; filling and blocking of drainage and road ditches; road deterioration; and ecological damage to forests, parklands, and wetlands. The effects of levee breaches and flooding on soils and soil productivity are seldom determined since updated soil surveys are not routinely made in response to levee breach and flooding. In the case of the O'Bryan Ridge gully field, the damage to soils included the permanent loss of $30 \%$ of the agricultural productive capacity as result of land use conversion, land scouring, water erosion, and gully field formation with little deposition of sediments since the rushing floodwaters drained quickly from the field except for 8.4 ha $(21 \mathrm{ac})$ of ponds at the bottom of the deep gullies. 


\section{RECOMMENDATIONS}

The USACE, the Mississippi River Commission, and the USDA Natural Resource Conservation Service should develop an agreement to immediately update the soil survey maps, conduct a land scouring and deposition survey, and create a soil conservation plan to ensure a rapid federal response after every levee breach and subsequent flooding event. This should be part of the federal government emergency response to a disaster, which provides funds for restoration and repair work, including opening drainage ditches, levee repairs, crater lake filling, gully repairs, restoration of land-scoured areas, and sand deposit removal.

\section{ACKNOWLEDGEMENTS}

Partial funding for this research was provided by the Iowa Agriculture and Home Economics Experiment Station, College of Agriculture and Life Sciences at Iowa State University. Additional funding support comes from National Great Rivers Research and Education Center, Regional Research Project Number 15-372 and in cooperation with NorthCentral Regional Project NCERA-3 Soil Survey; and published with funding support from the Director of the Illinois Office of Research, College of Agricultural, Consumer, and Environmental Sciences, University of Illinois, Urbana, Illinois.

\section{REFERENCES}

Abdollahi, L., and L.J. Munkholm. 2014.Tillage system and cover crop effects on soil quality: I. Chemical, mechanical, and biological properties. Soil Science Society of America Journal 78:262-270.

Barry, J.M. 1997. Rising Tide: The Great Mississippi Flood of 1927 and How It Changed America. New York: Simon \& Schuster.

Bruneta, R.C., and K.B.Astin. 2008. A comparison of sediment deposition in two adjacent floodplains of the River Adour in southwest France. Journal of Environmental Management 88:651-657.

Camillo, C.A. 2012. Divine Providence: The 2011 Flood in Mississippi River and Tributaries Project. Vicksburg, MS: Mississippi River Commission.

Goodwell, A.E., Z. Zhu, D. Dutla, J.A. Greenberg, P. Kumar, M.H. Garcia, B.L. Rhoades, R.R Holmes, G. Parker, D.P. Berretta, and R.B. Jacobson. 2014. Assessment of floodplain vulnerability during extreme Mississippi River flood 2011. Environmental Science and Technology 8(5):2619-2625, dx.doi.org/10.1021/es404760t.
Londono, A.C., and M.L. Hart. 2013. Landscape response to the intentional use of the Birds Point New Madrid Floodway on May 3, 2011. Journal of Hydrology 489:135-147.

Lowery, B., C. Cox, D. Lemke, P. Nowak, K.R. Olson, and J. Strock. 2009. The 2008 Midwest flooding impact on soil erosion and water quality: Implications for soil erosion control practices. Journal of Soil and Water Conservation 64(6):166A, doi:10.2489/jswc.64.6.166A.

Morton, L.W., and K.R. Olson. 2013. Birds Point-New Madrid Floodway: Redesign, reconstruction and restoration. Journal of Soil and Water Conservation 69(2):35A-40A, doi:10.2489/jswc.68.2.35A.

Morton, L.W., and K.R. Olson. 2014. Addressing soil degradation and flood risk decision making in levee protected agricultural lands under increasingly variable climate conditions. Special issue on Environmental Degradation. Journal of Environmental Protection 5(12):1220-1234.

National Research Council (NRC). 2012. Corps of Engineers Water Resources Infrastructure: Deterioration, Investment or Divestment. Committee on US Army Corps of Engineers Water Resources Science, Engineering and Planning; Water Science and Technology Board; Division on Earth and Life Studies; National Research Council National Academies Press. http://www.nap.edu/catalog. php?record_id $=13508$.

Olson, K.R. 2009. Impacts of 2008 flooding on agricultural lands in Illinois, Missouri, and Indiana. Journal of Soil and Water Conservation 64(6):167A-171A, doi:10.2489/jswc.64.6.167A.

Olson, K.R., and J.M. Lang. 2000. Optimum crop productivity ratings for Illinois soils. Bulletin 811. Urbana, IL: University of Illinois, College of Agricultural, Consumer, and Environmental Sciences, Office of Research.

Olson, K.R., and L.W. Morton. 2012a. The impacts of 2011 induced levee breaches on agricultural lands of Mississippi River Valley. Journal of Soil and Water Conservation 67(1):5A-10A, doi:10.2489/jswc.67.1.5A.

Olson, K.R., and L.W. Morton. 2012b. The effects of 2011 Ohio and Mississippi River valley flooding on Cairo, Illinois, area. Journal of Soil and Water Conservation 67(2):42A-46A, doi:10.2489/ jswc.67.2.42A.

Olson, K.R., and L.W. Morton. 2013a. Restoration of 2011 flood damaged Birds Point-New Madrid Floodway. Journal of Soil and Water Conservation 68(1):13A-18A, doi:10.2489/jswc.68.1.13A.
Olson, K.R., and L.W. Morton. 2013b. Soil and crop damages as a result of levee breaches on Ohio and Mississippi rivers. Journal of Earth Science and Engineering 3:139-158.

Park, J.T., P. Seager, S.C. Rao, N. Convertino, and I. Linkov. 2013. Integrating risk and resilience approaches to catastrophe management in engineering systems. Risk Analysis 33(3):356-367.

Ruehlmann, J., and M. Körschens. 2009. Calculating the effect of soil organic matter concentration on soil bulk density. Soil Science Society of America Journal 73:876-885.

Sloan, J.J., and D. Cawthon. 2003. Mine soil remediation using coal ash and compost mixtures. In Chemistry of Trace elements in Fly Ash, ed. K. Sajwan. New York, NY: Kluwer Academic/ Plenum Publishers.

Stavi, I., R. Lal, S. Jones, and R.C. Reeder. 2012. Implications of cover crops for soil quality and geodiversity in a humid-temperate region in the Midwestern USA. Land Degradation and Development 23:322-330.

White, C.S., R. Aguilar, and S.R. Loftin. 1997. Application of biosolids to degraded semiarid rangeland: Nine-year responses. Journal of Environmental Quality 26:1663-1671. 